\title{
4 Agency and Its Limits: African Unionists as Africa's "Vanguard" at the FDGB College in Bernau
}

On January 30, 1961, Werner Raase's term of office ended abruptly. Raase had served as the first director of the Institut für Ausländerstudium (Institute for Foreign Students), the most recent institution added to the East German trade union college, the Hochschule der Deutschen Gewerkschaften "Fritz Heckert" in Bernau near Berlin. Only one day earlier, the responsible federal executive of the central trade union federation which ran the college, the Freie Deutsche Gewerkschaftsbund (FDGB), had decided to dismiss four persons: Raase and his deputy, a teacher and an interpreter. ${ }^{2}$

The FDGB executive criticized not only the theoretical and didactic shortcomings in the teaching of state-socialist Marxism-Leninism, for which Raase was held responsible. The decision to dismiss him was also based on an intervention by 17 African students, whose request for a talk led high-ranked members of the Abteilung Internationale Verbindungen (International Relations Department) of the federal executive to travel to Bernau. ${ }^{3}$ The accusations subsequently collected were serious. In addition to the criticism of insufficient "political leadership" of the institute's directorate, ${ }^{4}$ the second major point of critique were racist statements made by Raase and other teachers. For example,

1 This essay is based on my MA thesis published in 2018, in which the third Afro-Asian course at the FDGB college from 1961 to 1963 is analyzed in a praxeological and microhistorical investigation. With regard to African students, the analysis focuses not only on their agency, but also on their social background and motivations for studying in the GDR as well as their actions. Passages of the work are also contained in this essay; see Eric Angermann, “'Ihr gehört auch zur Avantgarde’: African trade unionists at the FDGB’s academy Fritz Heckert (1961-1963)” (Master’s thesis, Georg-August-Universität Göttingen, 2018). I thank Tenzin Sekhon very much for his support in the translation of my contribution into English and Immanuel R. Harisch for his helpful remarks.

2 "Sekretariatsvorlage: Maßnahmen zur Verbesserung der Arbeit am Ausländerinstitut der Hochschule der Deutschen Gewerkschaften”, January 19, 1961, 1, Stiftung Archiv der Parteien und Massenorganisationen der DDR im Bundesarchiv, Berlin (henceforth: SAPMO-BArch), DY $79 / 406$.

3 Ibid., 3.

4 "Abschlußanalyse des 2. Lehrgangs für afro-asiatische Studenten an der Hochschule der Deutschen Gewerkschaften 'Fritz Heckert”, September 1960 - Mai 1961, June 2, 1961, 5, SAPMO-BArch, DY 79/406.

Ә OpenAccess. ( 2021 Eric Angermann, published by De Gruyter. (cc) BY This work is licensed under the Creative Commons Attribution 4.0 International License. https://doi.org/10.1515/9783110623543-004 
whilst drunk, he had supposedly claimed that in order to receive a suit in the GDR, one had to come from Africa. Similarly, the teacher who was also dismissed had allegedly said: "You come with empty suitcases and leave with full suitcases". ${ }^{5}$ These hostile remarks pointed to the fact that the incoming students of the FDGB's trade union college were provided with clothing such as suits - a policy which aggravated social envy and xenophobia.

The "existence of nationalist arrogance", as the FDGB executive called the racist remarks, was one of the decisive reasons for their dismissal. ${ }^{6}$ Even though the responsible FDGB offices had already criticized Raase beforehand, it was apparently the intervention of African students that was the immediate cause for his sacking. Some students had explicitly threatened to abandon their studies. ${ }^{7}$

It was precisely this threat by the students from Ghana and Mali, whose respective home countries were promoting socialist policies at the time, that would probably have meant a foreign policy setback for the GDR. In times of the West German Hallstein Doctrine-and several years before the GDR succeeded in establishing places of socialist encounters in the Global South ${ }^{8}$-was the provision of study places at the FDGB college for foreign trade unionists, mainly from African countries, who came to the GDR at the beginning of the 1960s, a significant project in East Germany's international solidarity work, in which the FDGB assumed a "leadership role". ${ }^{9}$ The course in Bernau targeted a social group in which the FDGB invested political hopes. This was based on the ideology of Marxism-Leninism - according to George Bodie, a fundamental factor of the "pedagogical model of the GDR"10 - which, in its historical determinism, assigned a central, progressive role in the struggle for world socialism to the trade unions prominently involved in decolonization struggles in the Global

5 "Sekretariatsvorlage: Maßnahmen zur Verbesserung der Arbeit am Ausländerinstitut der Hochschule der Deutschen Gewerkschaften”, January 19, 1961, 4, SAPMO-BArch, DY 79/406.

6 Ibid.

7 Ibid., 3.

8 See Jörg Depta and Anne-Kristin Hartmetz, this volume.

9 Gregory Witkowski, "Between Fighters and Beggars: Socialist Philantrophy and the Imagery of Solidarity”, in Comrades of Color: East Germany in the Cold War World, ed. Quinn Slobodian (New York: Berghahn Books, 2015), 75. For the role of the FDGB as an instrument in the foreign policy recognition efforts of the GDR see Ilona Schleicher, "Elemente entwicklungspolitischer Zusammenarbeit in der Tätigkeit von FDGB und FDJ", in Entwicklungspolitische Zusammenarbeit in der Bundesrepublik Deutschland und der DDR, ed. Hans-Jörg Bücking (Berlin: Duncker \& Humblot, 1998), 112-113.

10 George Bodie, "Where Do Correct Ideas Come From? The FDGB Institute for Foreign Students and the Coming of the Sino-Soviet Split" (paper presented at the conference Socialist Educational Cooperation with the Global South, Gießen, Germany, May 11-12, 2018), 6. 
South. The assessment was based on the marginal spread of communist parties, especially in sub-Saharan Africa. Furthermore, the orthodox notion of historical materialism necessitated an expectation that the working class should be united primarily in trade unions as the "class organization[s] of the proletariat". ${ }^{11}$

Thus, in this case it was not only a matter of the diplomatic recognition of the GDR as a sovereign state, but also of the projection of a vanguard onto the African trade unionists, who in this sense played an important role in the state-socialist ideas of a socio-political transformation. ${ }^{12}$ In the so-called afroasiatische Lehrgänge (Afro-Asian courses) of the Bernau institute, then, "classconscious, modest, sacrificial trade union functionaries" were to be instructed on how to organize and educate the "working class of Africa as the vanguard of the African peoples [...] for the improvement of working and living conditions". ${ }^{13}$ Furthermore, these "solidarity measures" were linked to the goal of "effective support for the anti-imperialist, anti-colonial, national liberation struggles". ${ }^{14}$

This contribution focuses precisely on this alleged vanguard of Africa, which in the early 1960s went to study at the FDGB college as one of the most important East German places of transnational socialist encounter. In contrast to aspects of their social mobility, discussed by Immanuel R. Harisch, ${ }^{15}$ the analysis focuses on the agency of the African trade unionists vis-à-vis the institute's directorate and the FDGB officials on the ground. I argue that, on the one hand, the (almost exclusively male) African course participants ${ }^{16}$ knew how to use the vanguardconcept they were studying, as well as the unstable foreign policy situation of

11 Friedrich Engels, "Brief an Bebel”, in MEW vol. 19 (Berlin: Dietz, 1973), 6.

12 Immanuel R. Harisch, “'Mit gewerkschaftlichem Gruß!' Afrikanische GewerkschafterInnen an der FDGB-Gewerkschaftshochschule Fritz Heckert in der DDR”, Stichproben. Vienna Journal of African Studies 34 (2018): 82-83; Schleicher, "Elemente entwicklungspolitischer Zusammenarbeit”, 111-112.

13 "Sekretariatsinformation: Analyse der Arbeit im 3. afro-asiatischen Lehrgang an der Hochschule der Deutschen Gewerkschaften 'Fritz Heckert”, May 6, 1963, 2, SAPMO-BArch, DY 79/ 2500.

14 "Präsidiumsvorlage zur Arbeit des FDGB und seiner Gewerkschaften nach Afrika", January 11, 1960, 3-4, SAPMO-BArch, DY 79/406.

15 Harisch, 'Mit gewerkschaftlichem Gruß!', 97-100.

16 Most of the course participants (hardly surprisingly) came from the working class. Most of them were originally office workers (in public service, as teachers or in the health sector) or dock and port workers, "trade workers" or railroad workers in the transport industry. However, in retrospect it is not possible to reconstruct which trade unionists already worked as functionaries at the beginning of the course. But after their studies in Bernau, several participants took over high positions in their trade unions. For more details on their social background see Angermann, 'Ihr gehört auch zur Avantgarde', 53-61. 
the GDR, to improve the teaching and living conditions at the FDGB college to their benefit. As the introductory example shows, the trade unionists of the Global South were also able to intervene against racist incidents with some success.

On the other hand, the African trade unionists, who, in their role as students in Bernau, appropriated such projections (stubbornly or eigen-sinnig ${ }^{17}$ ) as selfimages, also had to face the limits of their agency. Although they were able to protest openly against the responsible functionaries without the risk of having to suffer repressive measures - in contrast to the East German population, which as a rule had only "silent forms of defiance"18 at its disposal - the scope of action of the African course participants and that of the autochthonous inhabitants of the GDR were similar in terms of political options. Regardless of social origin and temporary or permanent residence, "small people" in the GDR only had "power and regulatory competence" in the surrounding lifeworlds. ${ }^{19}$ The possibilities of influence beyond one's own, social everyday life were severely limited due to the "all unifying central power"20 of the ruling Sozialistische Einheitspartei Deutschlands (SED) and its mass organizations - such as the FDGB. Given this context, the participants in the third Afro-Asian course were not in a position to water down the all-encompassing and universally valid claim to power of one party and initiate political activities that bypassed official institutions. On the contrary, despite all proclamations of international solidarity and equality, they also experienced the power techniques of SED rule. Consequentially, they were treated more as subjects of paternalist protection than as trade unionist Kollegen (colleagues). ${ }^{21}$

This will be demonstrated through a microhistorical analysis of a concrete conflict between students of the third Afro-Asian course and the institute's directorate. After half a year of study, the vast majority of the course called for an independently operating Afro-asiatisches Komitee (Afro-Asian Committee) to establish, amongst other things, anti-racist educational work for East German workers. In so doing, they implicitly questioned the SED's top-down claim to

17 For an English definition of Eigen-Sinn see Alf Lüdtke, The History of Everyday Life: Reconstructing Historical Experiences and Ways of Life (Princeton: University Press, 1995), 313-314. 18 Raul Zelik, "Nach dem Kapitalismus: Warum der Staatssozialismus ökonomisch ineffizient war und was das für Alternativen heute bedeutet”, Prokla. Zeitschrift für kritische Sozialwissenschaft 39 (2009): 213.

19 Thomas Lindenberger, introduction to Herrschaft und Eigen-Sinn in der Diktatur: Studien zur Gesellschaftsgeschichte der DDR (Köln: Böhlau, 1999), 31.

20 Lindenberger, Herrschaft und Eigen-Sinn, 36.

21 This is the common jargon used to address course participants or trade union representatives. Kollege is the common form of address within or between trade unions; it symbolizes the idea of equality of all trade union members. The English equivalent is brother or sister. 
sole leadership and its claims over the interpretation of social conditions in the GDR.

The presentation of this conflict outlines the different ways of interpretation of the African course participants at the college, which were heterogeneous, ambivalent, and not always consistent. Last but not least, I will show to what extent the FDGB functionaries, together with the institute's directorate, reacted to the criticism of the students they called the vanguard and made (or had to make) concessions to them, but also how they worked out disciplinary measures and partially adapted and appropriated the content of the protest.

The central arena of the conflict was the Rat der Delegationsleiter (Council of Heads of Delegation), which was established by the institute as a result of the intervention against the former institute's leader Werner Raase. The emergence of the council is evidence of an appropriation of agency by African trade unionists. The council was the only body through which course participants could participate in decision-making processes through their delegation representatives. ${ }^{22}$ At first, however, they were only allowed to "help" the institute's directorate to successfully run the course by communicating "wishes". ${ }^{23}$ The African representatives were also initially not allowed to set their own agenda items at the meetings. $^{24}$

Even though the institutionally granted competencies were extremely limited, the Council of Heads of Delegation was nevertheless a site for voicing complaints about the institute's directorate's actions. The social conditions experienced by the African students were articulated and their objections, in some cases, even led to success. The close connection of the council to the new head of the institute, Heinz Deutschland, ${ }^{25}$ and the institute's directorate, how-

22 Each national trade union federation represented at the college by students provided a delegation. The heads of delegation were to be elected by their Kollegen or had already been appointed by the sending trade union in advance; see "Schulordnung der Hochschule der Deutschen Gewerkschaften 'Fritz Heckert”, no date, 7, SAPMO-BArch, DY 79/270.

23 Ibid., 6.

24 "Protokoll über die Sitzung des Rates der Delegationsleiter", March 20, 1962, 4, SAPMOBArch, DY 79/2500.

25 Shortly before the beginning of the third Afro-Asian course, Heinz Deutschland started his work as institute director. The historian, who was only 27 years old at the time, had a model East German career to this point. Born in Bernau, he came from a working class family and first learned the profession of a lathe operator. After joining the SED and the FDGB he studied economics and history in Berlin and Moscow and was a research assistant at the FDGB college, until he finally took over the directorate of the Institute for Foreign Students; see Hella Karden, "Deutschland, Heinz", in Biographisches Handbuch der SBZ/DDR: 1945-1990. Bd. 1: Abendroth - Lyr, ed. Gabriele Baumgartner and Dieter Hebig (München: De Gruyter Saur 1996), 119. 
ever, made apparent the goals of the FDGB to control and discipline all initiatives. ${ }^{26}$ This was also evident in the largest protest during the third course.

\section{"Vanguardist" Complaints}

On March 17, 1962, the heads of delegation of the course met informally, deliberately excluding the institute's directorate, to discuss several problems within the course. ${ }^{27}$ The primary reason for the meeting was the discussion on the "formation of a committee" which, according to the Nigerian representative, would enable the student body to act independently "as a collective” and implement measures in the future. ${ }^{28}$ Furthermore, his colleagues argued for a joint place for understanding trade union work, ${ }^{29}$ "political issues", and for informing one another "about the situation of the working class in our countries"; after all, pan-

26 However, Heinz Deutschland, who lives in Berlin today, emphasizes retrospectively that discussions generally took place on an equal footing under his leadership; for example, about different ideas of socialism, see Heinz Deutschland, e-mail message to Immanuel R. Harisch, September 2, 2018. Further references in the written sources also speak for a more empathetic and collegial climate under Heinz Deutschland. For example, after the end of the course, there was a regular correspondence between him, who was hardly older or even younger than many of the participants in the course, and some of the graduates for several years; see Angermann, 'Ihr gehört auch zur Avantgarde', 46-47, 75-76. Of course, these friendships could not dissolve the structural power relations at the institute.

27 Nevertheless, there is a protocol written in German, which appears to be official. According to Heinz Deutschland, this was based on the notes of two of the institute's interpreters who were present at the meeting: "I remember that the transcript of the meeting of the heads of delegation on March 17, 1962 was made on the basis of the notes of the two interpreters Ursula Hofmann (English) and Christel Herz (French), after we [...] had heard about this meeting. Apart from their mother tongue, the African colleagues only spoke the language of the respective former or still colonial power, English or French. They had therefore asked the interpreters they knew to help them. Both colleagues had become accustomed to writing down key points or even longer sentences for their translations, because the African colleagues were not used to taking breaks and giving the interpreter the opportunity to translate. This was also necessary in this case because the explanations had to be translated first into German and then as precisely as possible into English or French. Thus, on the basis of these notes of the two colleagues, a basis existed for the reconstruction of the essential content of the explanations of the heads of delegation, partly in indirect speech and partly even literally.” Heinz Deutschland, e-mail message to Immanuel R. Harisch, August 23, 2020.

28 "Niederschrift über eine Zusammenkunft der Delegationsleiter", March 17, 1962, 1, SAPMOBArch, DY 79/2500.

29 "Protokoll über die Sitzung des Rates der Delegationsleiter", March 20, 1962, 13, SAPMOBArch, DY 79/2500. 
African "unity" to fight together against Western capitalist "imperialism" was the proclaimed goal. ${ }^{30}$

For African students adhering to a socialist-influenced pan-Africanism continental unity was paramount compared to the unity of the state-socialist camp which was propagated at the college. Thus, the dominant idea of pan-Africanism was clearly a central, thought-provoking impulse for the debate on sense and purpose of the committee. This was demonstrated at the subsequent council meetings where the heads of delegations clarified their ideas. The head of the Ghanaian delegation J. A. Osei ${ }^{31}$ stated that "Africa in its entirety" was to be represented by the committee, ${ }^{32}$ uniting the "builders" of the African continent. ${ }^{33}$

Such self-positioning revealed that the political designation as vanguard was also, in part, a self-perception. Although the political conditions in their home countries varied strongly, ${ }^{34}$ the delegation leaders saw their role in developing "a common political strategy" for the respective "national liberation struggle" in their home countries and "against capitalism" in general. They thereby also saw their studies as an opportunity for future political struggles - after all, "the opportunity to meet is better here [...] than in Africa". ${ }^{35}$

The few Asian delegations, which provided just five percent of the course, ${ }^{36}$ were also in favor of the committee. It is noticeable, however, that their African

30 "Niederschrift über eine Zusammenkunft der Delegationsleiter", March 17, 1962, 1, SAPMOBArch, DY 79/2500.

31 For the Ghanaian unionist J. A. Osei see Osei, annotated by Immanuel R. Harisch, this volume.

32 "Protokoll über die Sitzung des Rates der Delegationsleiter", March 20, 1962, 12, SAPMOBArch, DY 79/2500.

33 Ibid., 7.

34 The African students at the Bernau college came from a wide range of countries. A number of the politically independent states endured a rather peaceful transition to the postcolonial government, while others had to experience military violence and oppression of the colonial powers, Furthermore, there were the still colonial territories where African liberation movements were starting to be engaged in guerilla wars alongside the colonial settler regimes like South Africa and South-Rhodesia, where political participation and independence seemed to be far away. The independent African states which had a presence of students in Bernau varied in their political orientation - some were closer to the state-socialist countries, others to the Western-liberal bloc.

35 "Protokoll über die Sitzung des Rates der Delegationsleiter", March 20, 1962, 18, SAPMOBArch, DY 79/2500.

36 “3. Lehrgang - September 1961-März 1963”, n. d., 1-2, SAPMO-BArch, DY 79/439. 
fellow students rarely made reference to Asia when they spoke of "unity". ${ }^{37}$ Furthermore, only the Sri Lankan delegate is cited as a participant in the discussion in the protocol. ${ }^{38}$ The East German teachers, too, generally only referred to their African students during the entire course. The social and political upheavals in Africa at the beginning of the 1960s were the most likely places of social-revolutionary imaginations for East German trade union functionaries of that period, highlighting Africans as (supposedly) revolutionary subjects.

Therefore, the broadly supported proposal of the committee is by no means to be understood as a fundamental opposition against the East German institute's directorate or state socialism in general. At the first informal meeting, several heads of delegation stressed that they did not want to openly oppose the Institute for Foreign Students and praised the commitment of their teachers. Only Tanganyika's unidentified representative, who emphasized his union's membership in the ICFTU, ${ }^{39}$ openly criticized the situation. In his view, the students of the course had been used as a "tool” for "propaganda [...] against West Germany and America", which in the future had to be stopped by the committee. ${ }^{40}$ His view was quickly contested by other heads of delegation who claimed that the major common enemy was imperialism. ${ }^{41}$

Still, a large number of other course participants were also annoyed at being objectified in the FDGB's declaration of International Solidarity as part of the East German state socialist agenda, which subsequently confirmed an identity-forming self-image. ${ }^{42}$ This concerned, first and foremost, the instrumentalization of students during public events such as solidarity conferences. The institute did not even "ask" the students to participate, but "instructed" them to do so. ${ }^{43}$ At

37 One of the rare examples for the reference to the Asian fellow students is the already described statement of J. A. Osei, see "Protokoll über die Sitzung des Rates der Delegationsleiter", March 20, 1962, 7, SAPMO-BArch, DY 79/2500.

38 As an example see "Protokoll über die Sitzung des Rates der Delegationsleiter", March 20, 1962, 29, SAPMO-BArch, DY 79/2500.

39 This refers to the International Confederation of Free Trade Unions (ICFTU), which brought together the Western-oriented trade unions worldwide. The ICFTU competed with the Communist World Federation of Trade Unions (WFTU) from which it split in 1949 due to strategic Cold War considerations.

40 “Niederschrift über eine Zusammenkunft der Delegationsleiter”, March 17, 1962, 2, SAPMOBArch, DY 79/2500.

41 Ibid., 3.

42 See for the problems of the East German solidarity work Toni Weis, "The Politics Machine: On the Concept of 'Solidarity' in East German Support für SWAPO”, Journal of Southern African Studies 37 (2011): 352.

43 "Protokoll über die Sitzung des Rates der Delegationsleiter", March 20, 1962, 29, SAPMOBArch, DY 79/2500. 
the same time, the heads of the institutes had not communicated any information about the content of the public events in advance, while the students present on site were introduced as official representatives of their trade unions without prior notice. The South African representative Gilbert Hlabukana pointed out why this put the course participants at risk. The reporting of the conferences by the state media would endanger " $50 \%$ of all the colleagues studying here" who "live in illegality" and whose "necks are put on the line". ${ }^{44}$ Additionally, Hlabukana argued, he himself had been commissioned by his trade union confederation ${ }^{45}$ to speak at conferences about the conditions in his country, which was "in the depths of fascism", but only on the condition that "published photos of himself were to be avoided". ${ }^{46}$

In the course of the discussion, it became evident that experiences of racism were the primary reason for the attempt to initiate an Afro-Asian committee as an independent institution. African course participants criticized the representation of the social conditions in their home countries in East German publications. ${ }^{47}$ The Guinean Daouda Camara singled out a brochure entitled Bei Freunden im freien Afrika (With friends in free Africa), which described "an outdated state of Guinea" as a country without any car traffic. ${ }^{48}$ The Senegalese delegation leader Amadou-Lamine Diop was angered by the racist imagery of a caricature depicting a sleeping child on the back of an elephant particularly, claiming that this was "the same propaganda" that "the imperialists spread about Africa" ${ }^{49}$ With the planned committee, however, a possibility for intervention could be created, "in order to enlighten the people here about the real circumstances" and to enforce "that such nonsense is no longer published", the Moroccan representative announced..$^{50}$

In this sense, not only future stereotypical representations were to be prevented, but involvement "in the upbringing and development of the masses in the GDR" with regard to the conditions in Africa was to be implemented ${ }^{51}-$ al-

\section{Ibid., 10.}

45 This was the ANC-affiliated South African Congress of Trade Unions (SACTU).

46 "Protokoll über die Sitzung des Rates der Delegationsleiter", March 20, 1962, 10, SAPMOBArch, DY 79/2500.

47 On this issue, see also George Bodie's contribution in this volume.

48 "Protokoll über die Sitzung des Rates der Delegationsleiter", March 20, 1962, 17, SAPMOBArch, DY 79/2500.

49 Ibid., 32.

50 "Niederschrift über eine Zusammenkunft der Delegationsleiter”, March 17, 1962, 3, SAPMOBArch, DY 79/2500.

51 "Protokoll über die Sitzung des Rates der Delegationsleiter", April 3, 1962, 5, SAPMO-BArch, DY $79 / 2500$. 
though certain reservations also appeared in light of past experiences of racist ways of thinking, acting, and representing. A colleague from Cameroon, for example, expressed his disappointed hopes. Upon his arrival in the GDR, he would have believed "to come to a paradise" - but that was "not so", because "the European" would "always remain a European". ${ }^{52}$ Such incidents were by no means isolated. Black students from Sub-Saharan Africa described racist behavior which they encountered on a daily basis. For example, "anonymous letters" were circulating in the vicinity of the college in which "German girls" were called upon to not "flirt with their African colleagues". ${ }^{53}$ The Togolese representative Benoît Agbetrobu complained that the girlfriend of a fellow student from his delegation had received such a letter, an event which he called "very strange in a socialist or communist country". 54

But even the college itself was not free of discrimination. At the beginning of the course, students had already complained to the head of the institute, Heinz Deutschland, about an employee of the school restaurant. In this specific instance, the annoyance stemmed from the fact that no consequences were noticeable. ${ }^{55}$ Even fellow East German students stood out negatively. For example, Osée Mbaitjongue from Cameroon recalled a meeting with a guest of his Betreuer and room-mate, ${ }^{56}$ who accused him of "becoming a minister and having several women" upon his return to Cameroon, and that he could provide these women if he came to visit. On top of that, another East German student at the college had grabbed his hair without offering an explanation. ${ }^{57}$ Daouda Camara also reported on fellow East German students who had asked him whether people carried "a rifle" in Guinea "because of all the predators". ${ }^{58}$

52 "Niederschrift über eine Zusammenkunft der Delegationsleiter”, March 17, 1962, 3, SAPMOBArch, DY 79/2500.

53 "Protokoll der Sitzung des Rates der Delegationsleiter", April 10, 1962, 2, SAPMO-BArch, DY $79 / 2500$.

54 Ibid., 6.

55 Ibid., 6, 11.

56 These mentors were students from the GDR with whom the course participants shared their double rooms; see Ilona Schleicher, "FDGB-Offensive in Westafrika: Der Gewerkschaftsverbund im Jahr Afrikas”, in Engagiert für Afrika: Die DDR und Afrika II, ed. Ulrich van der Heyden et. al. (Münster: Lit, 1994), 89.

57 “Protokoll der Sitzung des Rates der Delegationsleiter”, April 10, 1962, 22, SAPMO-BArch, DY $79 / 2500$.

58 Ibid., 7. 
These examples reveal the dominant role sexualized perceptions played in the context of racist behavior towards fellow African inhabitants in the GDR. ${ }^{59}$ In general, and despite all official negations and an anti-fascist and anti-colonial self-idealization, they refer to the lingering effect of colonial imagery and racist ways of thinking about the exotic or original people of Africa in the GDR. ${ }^{60}$

\section{Responding Hosts}

Throughout the course of the conflict over the Afro-Asian Committee, the institute's directorate and the responsible representatives of the FDGB executive tried to settle the matter as quickly and quietly as possible. To this end, they engaged in lengthy discussions with the heads of delegations and made substantial concessions to them on some points. The Council of Heads of Delegation was given more time on a weekly basis in future, starting with its first official meeting after the informal meeting. In addition, the institute's directors Heinz Deutschland and Gerhard Hans expanded the opportunities for student participation by allowing delegations to submit their own agenda items. ${ }^{61}$ Furthermore, the status of students at international solidarity events, whose central role the East German hosts repeatedly emphasized for the common "struggle" against imperialism and for the "solidarity movement" in the GDR, was to be changed to the role of "observers". ${ }^{62}$ This could prevent them from being publicly seen as representatives, which then could have led to repression in their home countries, as the South African representative Gilbert Hlabukana had pointed out above. The institute's directorate also accepted criticism of representations in East German magazines and specialist journals voiced by the Guinean and Senegalese delegation. ${ }^{63}$ Addressing the FDGB executive responsible for media relations, college director Karl Kampfert subsequently ordered that "all photos or other pic-

59 For the distribution of the image of the "lascivious African man" see Sara Pugach, "African Students and the Politics of Race and Gender in the German Democratic Republic”, in Comrades of Color: East Germany in the Cold War World, ed. Quinn Slobodian (New York: Berghahn Books, 2015), 137-138.

60 Quinn Slobodian, "Socialist Chromatism: Race, Racism, and the Racial Rainbow in East Germany", in Comrades of Color: East Germany in the Cold War World, ed. Quinn Slobodian (New York: Berghahn Books, 2015), 26.

61 "Protokoll über die Sitzung des Rates der Delegationsleiter", March 20, 1962, 4, SAPMOBArch, DY 79/2500.

62 Ibid., 5.

63 Ibid., 6. 
torial material depicting Afro-Asian students from our institute for foreigners must be approved by the head of the institute before they can be published". ${ }^{64}$

The institute's directorate thus took up politically justifiable aspects of the students' demands, but from the outset it did not allow for the Afro-Asian committee to become an independent student initiative - even though its representatives avoided an official positioning at the first council meeting during the conflict. ${ }^{65}$ The Council of Heads of Delegation, to which the students only wanted to assign competencies concerning the organization of studies, ${ }^{66}$ was to be the only representative body for student interests. The "formation of such a committee", on the other hand, was supposedly unjustifiable - for it would have to subordinate itself to the "instructions of the institute's directorate", thereby limiting their right to make any independent decisions, as noted in a report on the first meeting addressed to the FDGB executive. ${ }^{67}$ This also highlighted the concern about a loss of political control. It was strictly rejected that a possible committee run by the African students could "uniformly impose demands on the directorate of the institute" and enforce them. ${ }^{68}$ The reason for the widespread "demand for such a committee" was not seen in the continuation of colonial relations between East Germans and the students of the Global South. Instead, those responsible in Bernau claimed that the ICFTU was trying to influence the course. ${ }^{69}$

The lack of self-reflection here and the reference to external manipulative forces can be explained by looking at the weaknesses of the Marxist-Leninist state doctrine. ${ }^{70}$ This is also indicated by the fact that the report quoted here was addressed to the FDGB executive, which in the centralist structure of the

64 This was based on "justified complaints"; see "Brief der Hochschuldirektion an den Sekretär der Kommission für Koordinierung und Qualifizierung des FDGB-Bundesvorstands”, May 4, 1962, 1-2, SAPMO-BArch, DY 79/183.

65 "Protokoll über die Sitzung des Rates der Delegationsleiter", March 20, 1962, 35, SAPMOBArch, DY 79/2500.

66 Ibid., 12.

67 "Einige Bemerkungen und Erläuterungen zum beiliegenden Protokoll und den damit verbundenen Problemen”, March 22, 1962, 4, SAPMO-BArch, DY 79/2500.

68 Ibid., 1.

69 Ibid., 3.

70 This "is based on a great optimism of progress and idealism. The idea of acting in accordance with historical laws, however, also reduces the willingness for reflection and self-criticism if the expected forecasts are not realized. If history is not understood as an open process, the absence of revolutions or even the emergence of authoritarian instead of emancipatory tendencies [or the emergence of intra-societal contradictions, note d. A.] can hardly be explained other than by manipulation of the masses and conspiracy of the ruling elites [...]”; see Moritz Zeiler, Materialistische Staatskritik: Eine Einführung (Stuttgart: Schmetterling Verlag, 2017), 42. 
GDR Federation of Trade Unions had the final decision-making power also with regard to the Institute for Foreign Students. ${ }^{71}$ Its directorate, with its very own motivation to create a good impression vis-à-vis the next highest authority, was itself looking for starting points for the rapid implementation of state socialist guidelines. This was accompanied by the fact that it was not so much the actual intentions of the protesting students that were at the center of the institute's own search for solutions, but rather exploring possibilities to homogenize the student collective. An external enemy had to be constructed, who would be held responsible for the "ddisturbances' [...] from outside". ${ }^{72}$ In addition to the speculations about the role of Western influence, in their criticism the institute's directorate singled out the Guinean Daouda Camara, who had been himself one of the sharpest critics of the institute's reaction, in its report from the protesters' camp. In the institute's view, Camara had allegedly tried to split the collective. ${ }^{73}$

\section{The Paternalism of Comradeship}

But Camara was by no means alone with his criticism. The apparent reluctance of the East German functionaries to give in to the demand for an Afro-Asian Committee was followed by incomprehension, indignation, and, in the end, intensified forms of protest on the part of the students. In the first council meeting, the heads of delegation involved in the discussion criticized the lack of approval for the committee by the institute's directorate, though some isolated voices were raised in appreciation of its efforts "to conduct the course and create favorable conditions for us". ${ }^{74}$ In this context, Camara implicitly threatened to leak information to the West. He stressed that it was not really in the interest of the protesters to read that "you are with so-called friends who oppose your unity in the imperialist press". ${ }^{75}$ De facto, however, he threatened to pass on the institute's

71 "Einige Bemerkungen und Erläuterungen zum beiliegenden Protokoll und den damit verbundenen Problemen”, March 22, 1962, 4, SAPMO-BArch, DY 79/2500.

72 Alf Lüdtke, ““... den Menschen vergessen’? - oder: Das Maß der Sicherheit: Arbeiterverhalten der 1950er Jahre im Blick von MfS, SED, FDGB und staatlichen Leitungen”, in Akten. Eingaben. Schaufenster. Die DDR und ihre Texte. Erkundungen zu Herrschaft und Alltag, ed. Alf Lüdtke and Peter Becker (Berlin: De Gruyter, 1997), 208-209.

73 "Einige Bemerkungen und Erläuterungen zum beiliegenden Protokoll und den damit verbundenen Problemen”, March 22, 1962, 3, SAPMO-BArch, DY 79/2500.

74 "Protokoll über die Sitzung des Rates der Delegationsleiter", March 20, 1962, 13, SAPMOBArch, DY 79/2500.

75 Ibid. 
disastrous assessment to the West German media if it were to oppose the formation of a committee. Camara's statement exemplifies how the students strategically used their socio-political position during the height of the Cold War to assert their own interests in the GDR.

At the following delegation council meeting two weeks later, the East German hosts nevertheless rejected the committee in the proposed form. Again, a representative of the International Relations Department of the FDGB executive was present. This "colleague Fischer" announced "on behalf of the federal executive" that, following agreements with FDGB Chairman Herbert Warnke and African trade union officials in Berlin and Prague, a "binding" decision had been made that the Council of Heads of Delegation was sufficient as the "only organ" for the institutional representation of the students. ${ }^{76}$ Although the committee could be founded, it would only carry out a cultural function and could not deal with the FDGB directly, as this would endanger its "principle of non-interference" ${ }^{77}$ It is obvious that Fischer here was referring to internationalist principles of Marxism-Leninism, which in terms of foreign policy included - officially - the "free self-determination" of nations and precisely "non-interference in the internal affairs of other states". ${ }^{78}$ Therefore, the committee could only address "matters of the African colleagues among themselves"79 and should not interfere in the home affairs of the GDR. Finally, it was argued that the Afro-Asian Committee would not have the right "to make any demands on school regulations". ${ }^{80}$ Fischer explicitly denied discussing the position of the FDGB executive. ${ }^{81}$

The East German representatives were met with a wave of indignation. Hamidou Diallo from Mali called for a discussion and explained that the students

76 "Protokoll über die Sitzung des Rates der Delegationsleiter", April 3, 1962, 1-3, SAPMOBArch, DY 79/2500.

77 Ibid., 18.

78 See as an exemplary contemporary source G. N. Zwektow, "Die Leninschen Prinzipien der sowjetischen Außenpolitik”, Gesellschaftswissenschaftliche Reihe 19 (1970).

79 "Protokoll über die Sitzung des Rates der Delegationsleiter", April 3, 1962, 1-3, SAPMOBArch, DY 79/2500, 9.

80 Ibid., 3.

81 Ibid. Looking back, Heinz Deutschland formulated an objection, which is more technical and bureaucratic than substantive: "The FDGB had contracts or agreements with the heads of the delegating organizations. These did not provide for the colleagues delegated to study in Bernau [...] to join forces with representatives of other organizations in an 'Afro-Asian committee'. We felt bound by these agreements.” Heinz Deutschland, e-mail message to Immanuel R. Harisch, August 23, 2020. 
felt like they were treated as "children" who did not know what they wanted. ${ }^{82}$ This was supported by Luc Bissay from Cameroon. The students in Bernau were themselves (partially full-time) trade unionists. For them, it was therefore irrelevant what African trade union officials in Berlin or Prague thought of the idea of a committee. ${ }^{83}$ Diallo also questioned the alleged talks with African trade union representatives and instead, together with other heads of delegation, referred to a core competence of the committee, namely educational work on life in Africa, a bottom-up approach for "the friendship between our peoples and the people of the GDR". ${ }^{84}$ In the permitted form, however, the committee would only be a "glass bowl" with no contact to its surrounding. ${ }^{85}$ Furthermore, it would be virtually impossible for the FDGB not to have any contact whatsoever with the committee, since without its assistance it could not be set up. Several heads of delegation also mentioned obvious distrust towards the students shown by the FDGB executive. ${ }^{86}$ In this sense, the FDGB was apparently "afraid" of the students, as soon as they would assume an active role. ${ }^{87}$

Despite all objections, the institute's directorate insisted on the refusal to establish the proposed Afro-Asian committee. Heinz Deutschland responded to the broad criticism by stating that "interference in the internal affairs of the GDR", which according to the FDGB included the establishment of "relations with the workers of the GDR", was unacceptable. ${ }^{88}$ The decision had been made "in accordance with the hundred-year-old principles of the German labour movement in relation to other foreign organisations". 89

Other explanations for the actions of the institute's directorate and the FDGB executive appear more plausible. It is more likely that the desire to intervene in the powers of the centralist party and trade union apparatus could not be permitted. The institute's directorate was well aware that "the demand for assistance in the education of the working class in the GDR" resulted from the statement - or "accusation", as it was called by the college - "that racism exists in the GDR, and not enough was being done from the official side against it".$^{90}$ The

82 "Protokoll über die Sitzung des Rates der Delegationsleiter", April 3, 1962, 1-3, SAPMOBArch, DY 79/2500, 4.

83 Ibid., 10.

84 "Protokoll über die Sitzung des Rates der Delegationsleiter", April 3, 1962, 5, 11, SAPMOBArch DY 79/2500.

85 Ibid., 11-12.

86 Ibid., 12.

87 Ibid., 18.

88 Ibid., 6-7.

89 Ibid., 19.

90 “Einschätzung”, n. d., 4, SAPMO-BArch, DY 79/2500. 
creation of the committee in the form proposed by the protesters would have meant an admission of social reality in the GDR with regard to widespread racism and of the fallibility of the prevailing ideology declared as true, which consequently questioned the party's leading role in state and society. The limitation of agency of the African trade unionists to act as students in Bernau was revealed at just this point, when they had in mind a self-organized political practice without constant paternalistic subordination to the SED organs. ${ }^{91}$

The council meeting further escalated after this. It ended abruptly after a dispute between several heads of delegation ${ }^{92}$ and an attempt at appeasement that was not further commented on: students were also offered to become members of the German-African Society, which was in line with the ruling party SED. They could inform them about the social conditions in Africa, without, of course, questioning positions of the SED and its associated mass organizations. ${ }^{93}$

As a response, the disappointed students turned to other means. The following day, the protesters declared a boycott of an excursion to the Brandenburg steel and rolling mill; apparently not a single student took part in the excursion. $^{94}$

91 Two years earlier, four African students from Nigeria, Uganda, and Togo had the same limitation of their agency in the Soviet Union. The students of the state Lomonosov University in Moscow founded in September 1960 the independent "Black Africans' Student Union”, for which they were expelled by the university. After returning to their home countries, the four scandalized their experienced restrictions and received great attention in Western print media; see Maxim Matusevich, "Expanding the Boundaries of the Black Atlantic: African Students as Soviet Moderns”, Ab Imperio 2 (2012): 339-340.

92 The Congolese representative Joseph Safily, who in the previous council meeting had been the only one to express criticism of the committee's demand (see "Niederschrift über eine Zusammenkunft der Delegationsleiter”, March 17, 1962, 4, SAPMO-BArch, DY 79/2500), came into the focus of his African Council colleagues. Safily accused the others of showing no real solidarity with their compatriots in times of the Congo crisis. As a result, the majority of the heads of delegations, some of whom had previously reported on trade union colleagues who had fallen in the Congo ("Protokoll über die Sitzung des Rates der Delegationsleiter", April 3, 1962, 16, SAPMO-BArch DY 79/2500), left the meeting "under loud protest”; see ibid., 20. Even after this premature end, the situation at the institute did not calm down. According to other students, Safily himself acted aggressively (see "Protokoll über die Sitzung des Rates der Delegationsleiter”, April 10, 1962, 4, 20, 23, SAPMO-BArch, DY 79/2500) and was ultimately expelled from the college for this; see "3. Lehrgang - September 1961 - März 1963”, n. d., 2, SAPMOBArch, DY 79/439.

93 "Protokoll über die Sitzung des Rates der Delegationsleiter”, April 3, 1962, 19, SAPMO-BArch, DY 79/2500

94 “Einschätzung”, n. d., 3, SAPMO-BArch, DY 79/2500. 
In order to pacify the protest at the institute and at the same time prevent the "formation of the committee as an official organ", which could potentially influence "internal affairs" and act as "appointed political representation", 95 the institute's directorate around Heinz Deutschland decided to take two steps. First, it attempted to socially "isolate" the most prominent protesters. ${ }^{96}$ These included the delegations from Ghana and Nigeria, which had advocated for a collective refusal to take part in regular classes the day following the boycott of the excursion, but were no longer able to mobilize the majority of the course participants. Clearly, proven forms of struggle from work experience as trade unionists were used by the students in the dispute. They called their actions a "strike" and claimed that the institute directors were "capitalists", while they themselves were oppressed "workers". ${ }^{97}$

The isolation of the main actors of the protest was supposed to happen primarily in class by the teachers; every "attempt at further political provocation" would be criticized "sharply and unequivocally". 98 This is related to the second measure adopted, namely the launch of a "comprehensive political offensive" in the course, whereby those deemed "the good forces" by the institute's directorate, essentially a large majority of the course without a clear position, would have their "back" strengthened in order to "assure their solidarity and support". ${ }^{99}$ To this end, the institute's directorate also decided to strengthen "cultural activities" with regard to the leisure time of the course participants. ${ }^{100}$ Last but not least, it planned to convene another meeting of the Council of Heads of Delegation, in order to prevent informal meetings of students which were described as "illegal". ${ }^{101}$ But it was also a large number of the students themselves who wanted to prevent further escalation of the committee dispute. Several representatives therefore went to one of the two deputy directors of the institute, Gerhard Hans, for a discussion in which they described the racist incidents they had experienced as one of the main reasons for their protest. This discussion, in which

95 Ibid., 1-2.

96 Ibid., 5.

97 “Einschätzung”, n.d., 3, SAPMO-BArch, DY 79/2500.

98 Ibid., 5.

99 Ibid.

100 Ibid. This decision was also taken to prevent the West Berlin visits already criticized at this time, which were considered a bad influence; for the possibilities of visits to West Berlin see Harisch, “"Mit gewerkschaftlichem Gruß!', 97.

101 “Einschätzung”, n. d., 5, SAPMO-BArch, DY 79/2500. 
the students present called for a meeting, also resulted in further unscheduled council meetings. ${ }^{102}$

\section{The Triumph of Dogma}

The meeting which was thus convened, and which lasted for a total of nine hours, clearly had the character of a debate. In addition to two representatives of the FDGB executive, Karl Kampfert, director of the whole FDGB college in Bernau, was present for the first time. With one exception, all heads of delegation attended the council meeting. ${ }^{103}$

Most of the meeting was devoted to finding a compromise on the committee question and discussing racist incidents at the college. Rolf Deubner, as one of the FDGB's executive representatives, made a clear separation between a political and a cultural sphere. He confirmed on the one hand the view that "political activity in the GDR" was not possible for the students; after all, this contradicted the "principles of proletarian internationalism", which also included "non-interference in the internal affairs of trade union organisations". ${ }^{104}$ On the other hand, he announced that the FDGB was now quite willing to support a committee with regard to possible events - as long as it only facilitated "cultural life". ${ }^{105}$

Subsequently, he answered the requests of some students and, as representative of the FDGB executive, took a stand on the various accusations of racism. ${ }^{106}$ He explained that "of course there are still numerous petty bourgeois people"-singling out people with their own small businesses and thus in possession of private property-"who are afflicted with the idea of the capitalist era" ${ }^{107}$ According to the ruling SED's state doctrine, this population group was regarded as the manipulated mass basis which had historically given rise

102 “Protokoll über die Sitzung des Rates der Delegationsleiter”, April 10, 1962, 13, SAPMOBArch, DY 79/2500.

103 The Congolese student Safily was only invited as "observer" and no longer as head of delegation; see Ibid., 8.

104 Ibid., 2.

105 Ibid., 2-3.

106 One week earlier, despite an urgent request to address this issue, the institute's directorate had still ignored the complaint of the Moroccan representative about an assault in the urban area of Bernau - at least the pedantic protocols allow this evaluation; see "Protokoll über die Sitzung des Rates der Delegationsleiter”, April 10, 1962, 1, SAPMO-BArch, DY 79/2500.

107 "Protokoll über die Sitzung des Rates der Delegationsleiter", April 10, 1962, 2, 24, SAPMOBArch, DY 79/2500. 
to fascism. ${ }^{108}$ Deubner made them responsible for the existing racism in orthodox Marxist fashion; they still had to be educated in the socialist sense to abandon their racist worldview. ${ }^{109}$

In doing so, he admitted the existence of racism in the GDR, but externalized it to a social group that was not yet socialist enough. The heads of delegation then described their own experiences at the college in an attempt to explain that racism had become a general problem of everyday life. The Cameroonian Luc Bissay tried to make his East German colleagues aware of this fundamental problem. They "should for once take our black skin, our hair" and would then "realize what problems are still open, what educational work still has to be done". 110

In the further course of the meeting, the East German representatives insisted on their one-dimensional economist analysis of racism. Nevertheless, in response to these reports and requests, Kampfert and Deubner promised to hold talks with conspicuous employees and students. ${ }^{111}$ "German colleagues" acting in a discriminatory way have "no place at the school", they argued. ${ }^{112}$ The East German announcements in this council meeting, which ultimately concluded the conflict, were a result of the protest practices of the African trade unionists studying in Bernau. They first made it possible to address racist incidents, and also achieved partial success with other demands, even if the constitution of a Afro-Asian committee was not initiated. This is illustrated by the measures announced by Heinz Deutschland as head of the institute. He reaffirmed the active participation in council meetings, which had been promised at the start of the whole conflict, and distributed a discussion paper containing suggestions for "improving cultural work and student care". ${ }^{113}$ Amongst other things, this included students "reporting on their countries" once a month, in alphabetical order. ${ }^{114}$ Furthermore, the institute's directorate proposed to increase the number

108 See Georgi Dimitroff, “Arbeiterklasse gegen Faschismus”, in Die Offensive des Faschismus und die Aufgaben der Kommunisten im Kampf für die Volksfront gegen Krieg und Faschismus. Referate auf dem VII. Kongreß der Kommunistischen Internationale (1935), ed. Institut für Marxismus-Leninismus (Berlin: Dietz, 1957), 91.

109 "Protokoll über die Sitzung des Rates der Delegationsleiter”, April 10, 1962, 24-25, SAPMOBArch, DY 79/2500.

110 "Protokoll über die Sitzung des Rates der Delegationsleiter”, April 10, 1962, 18, SAPMOBArch, DY 79/2500.

111 Ibid., 12.

112 Ibid., 26.

113 Ibid., 23.

114 “Protokoll über die Sitzung des Rates der Delegationsleiter", May 11, 1962, 2, SAPMO-BArch, DY 79/2500. 
of excursions, such as "sightseeing and theatre trips", and announced the establishment of a club room explicitly intended for the participants of the courses, which was also intended for political discussions amongst one another. ${ }^{115}$ Contact with the East German population-generally supervised with East German workers of certain selected workers' brigades-was also to be strengthened from now on. ${ }^{116}$ Just like at the beginning of the conflict, the institute's directorate carefully took up politically justifiable aspects of student demands without allowing independent student initiatives to be created; yet, subordination to the political control of the East German confederation of trade unions had to be maintained.

In the comments on the offers made by FDGB board member Deubner, one can see that despite all the disciplinary motives the imagination of a progressive - or even revolutionary - role of African trade unionists also determined the actions of their East German colleagues. According to Deubner, the "friends" from Africa "also belonged to the vanguard of the working class", which, according to the Leninist credo, stood for the "future" of their homelands. ${ }^{117}$ It was therefore essential that trade unionists inform each other "mutually" about their "countries", "cultures", and their respective "working classes" by means of the proposals submitted. ${ }^{118}$ It can be assumed that this political assessment of the visiting students was also a central aspect for the East German hosts' approach, which was by no means punitive and repressive, but always aimed at closer political integration.

Ultimately, the students accepted the solutions presented here. ${ }^{119}$ Some heads of delegation even praised the institute's efforts to create a calm atmosphere for discussion and to respond to their criticism. ${ }^{120}$ From this point on, the protocols and reports of the institute's directorate no longer contained any dissenting votes or demands for a committee; instead, several references to

115 “Protokoll über die Sitzung des Rates der Delegationsleiter”, May 11, 1962, 2, SAPMO-BArch, DY 79/2500.

116 Ibid.

117 Ibid., 23-24.

118 Ibid., 25.

119 At the following council meeting, the heads of delegation present approved the collected proposals without dissenting votes; see "Protokoll über die Sitzung des Rates der Delegationsleiter”, May 11, 1962, 2, SAPMO-BArch, DY 79/2500.

120 “Protokoll über die Sitzung des Rates der Delegationsleiter”, April 10, 1962, 15-17, SAPMOBArch, DY 79/2500. 
the real implementation of the institute's proposals can be found in the corpus of sources. $^{121}$

\section{Conclusion}

The results and the course of the conflict at the Bernau Institute for Foreign Students illustrate that African trade unionists were both seen as revolutionary subjects of Africa and treated as objects of constant paternalism. Their treatment as well as their political classification in East Germany resulted from the Leninist conception of a vanguard, in the shape of a leading party as the motor of social progress, upon which the GDR's power structure rested. Therefore, practices of all social milieus and groups were constantly subject to the "reservations of an elitist vanguard and its representatives"122 as well as the "authoritarian-paternalistic social structure" 123 of the state-socialist one-party system.

This also applied to the African trade unionists, with their specific cadre training and their supposed vanguardist position during their temporary stay in Bernau. As one of the social groups with an ascribed special historical role on the path to world socialism, the national trade union federation FDGB, acting as the transmission belt of the SED, attempted to politically bind the course participants to this doctrine, the supposed universal validity of which lay in the "historical violence"124 of the successful October Revolution. This motive for praxis illustrates the non-acceptance of any autonomous organizations beyond state-supporting structures, since these could have seen independent develop-

121 Regular contact with selected Socialist Brigades "in important production plants" was also implemented (see "Vorlage für die Institutsleitungssitzung am 25.5.62", May 24, 1962, 2, SAPMOBArch DY 79/409), as was the prompt establishment of the promised clubroom, which was available in the evening with a small library and magazines in several languages; see "Schulordnung der Hochschule der Deutschen Gewerkschaften 'Fritz Heckert”, n.d., 7, SAPMO-BArch, DY 79/ 270. In addition, they were more actively involved in the evaluation of teaching; see "Einladung zur Sitzung der Institutsleitung mit dem Rat der Delegationsleiter am 15.11.1962 in Lektionssaal 4", n.d., SAPMO-BArch, DY 79/2500; Protokoll über die Sitzung des Rates der Delegationsleiter, December 13, 1962, 2, SAPMO-BArch DY 79/2500.

122 Lindenberger, Herrschaft, 31.

123 Bernd Wagner, "Zu rechtsextremen Entwicklungen in den neuen Bundesländern”, in AfrikaBilder. Studien zu Rassismus in Deutschland, ed. Susan Arndt (Münster: Unrast, 2006), 110. 124 Hans-Jürgen Krahl, "Zu Lenin, Staat und Revolution”, in Konstitution und Klassenkampf. Zur historischen Dialektik von bürgerlicher Emanzipation und proletarischer Revolution. Schriften, Reden und Entwürfe aus den Jahren 1966-1970, ed. Hans-Jürgen-Krahl (Frankfurt: Neue Kritik, 1971), 182. 
ments, enabling political dissidence or oppositional attitudes. It is important to note that in the conflict analyzed here, those responsible in East Germany did not opt for repressive measures but for an even more intensive political integration that incorporated selected demands. However, this decision was not only based on the special position of the African trade union students, but also on their ability to make use of the unstable foreign policy situation of the GDR, thereby highlighting a particularly fragile aspect of the political control they faced. Nevertheless, the majority of the Africans studying in Bernau recognized the role of the East German trade unionists as esteemed ${ }^{125}$ providers of "political ideas" 126 and as profound experts of socialism as an exemplary developmental model, even if a considerable part favored alternatives such as a pan-African-influenced socialism. ${ }^{127}$

This also points to the reproductive character of the protests. Not only did the concessions obtained help the students to interact and communicate, they also expanded the institute's directorate course repertoire. It used these new structures for propagandistic work, for example to spread the image of an imperial West Germany, which certainly did not convince all course participants. ${ }^{128}$ They treated these new possibilities as another option for teaching Marxism-Leninism and ensuring a following in opposition to the inner-German opponent in the West. Last but not least, the protests shown here were an important step for the further establishment of studies for foreigners at the FDGB college, which 4,400 trade unionists, especially from the Global South, ${ }^{129}$ made use of until the end of the GDR.

125 Letter from Bernard Obua to Heinz Deutschland, August 8, 1964, 1, SAPMO-BArch, DY 79/ 2511.

126 Letter from Abdelkader Djoudi to Helmut Lehmann, August 27, 1963, 1, SAPMO-BArch, DY $79 / 616$.

127 In general, so-called "Maoist" ideas were also widespread; see Bodie, "The FDGB Institute," 22-23.

128 "Bericht über die Ergebnisse der Westberlindiskussion im 3. afro-asiatischen Lehrgang," October 9, 1962, 5, SAPMO-BArch, DY 79/2500.

129 Alfred Förster, Die FDGB-Bundesschule “Theodor Leipart” Bernau bei Berlin (Bernau: Verein Baudenkmal Bundesschule Bernau, 2007), 47. 


\section{Bibliography}

Angermann, Eric. “'Ihr gehört auch zur Avantgarde': African trade unionists at the FDGB's academy Fritz Heckert (1961-1963).” Master thesis, Georg-August-Universität Göttingen, 2018.

Bodie, George. "Where do Correct Ideas Come From? The FDGB Institute for Foreign Students and the Coming of the Sino-Soviet Split." Paper presented at the conference Socialist Educational Cooperation with the Global South, Gießen, Germany, May 11-12, 2018.

Dimitroff, Georgi. "Arbeiterklasse gegen Faschismus." In Die Offensive des Faschismus und die Aufgaben der Kommunisten im Kampf für die Volksfront gegen Krieg und Faschismus. Referate auf dem VII. Kongreß der Kommunistischen Internationale (1935), edited by Institut für Marxismus-Leninismus, 4-110. Berlin: Dietz, 1957.

Engels, Friedrich. "Brief an Bebel." In MEW vol. 19, 3-9. Berlin: Dietz, 1973.

Förster, Alfred. Die FDGB-Bundesschule "Theodor Leipart” Bernau bei Berlin. Bernau: Verein Baudenkmal Bundesschule Bernau, 2007.

Harisch, Immanel R. “'Mit gewerkschaftlichem Gruß!' Afrikanische GewerkschafterInnen an der FDGB-Gewerkschaftshochschule Fritz Heckert in der DDR”. Stichproben. Vienna Journal of African Studies 34 (2018): 77-109.

Karden, Hella. "Deutschland, Heinz." In Biographisches Handbuch der SBZ/DDR: 1945-1990. Bd. 1: Abendroth - Lyr, edited by Gabrielle Baumgartner and Dieter Hebig, 119. München: De Gruyter Saur, 1996.

Krahl, Hans-Jürgen. "Zu Lenin, Staat und Revolution.” In Konstitution und Klassenkampf. Zur historischen Dialektik von bürgerlicher Emanzipation und proletarischer Revolution.

Schriften, Reden und Entwürfe aus den Jahren 1966-1970, edited by Hans-Jürgen-Krahl, 182 -190. Frankfurt: Neue Kritik, 1971.

Lindenberger, Thomas. Introduction to Herrschaft und Eigen-Sinn in der Diktatur: Studien zur Gesellschaftsgeschichte der DDR, edited by Thomas Lindenberger, 13-44. Köln: Böhlau, 1999.

Lüdtke, Alf. ““... den Menschen vergessen’? - oder: Das Maß der Sicherheit: Arbeiterverhalten der 1950er Jahre im Blick von MfS, SED, FDGB und staatlichen Leitungen." In Akten. Eingaben. Schaufenster. Die DDR und ihre Texte. Erkundungen zu Herrschaft und Alltag, edited by Alf Lüdtke and Peter Becker, 57-75. Berlin: De Gruyter, 1997.

Lüdtke, Alf. The History of Everyday Life: Reconstructing Historical Experiences and Ways of Life. Princeton: University Press, 1995.

Mac Con Uladh, Damian. "Guests of the socialist nation? Foreign students and workers in the GDR, 1949-1990." PhD diss., University of London, 2005.

Matusevich, Maxim. "Expanding the Boundaries of the Black Atlantic: African Students as Soviet Moderns". Ab Imperio 2 (2012): 325-350.

Pugach, Sara. "African Students and the Politics of Race and Gender in the German Democratic Republic." In Comrades of Color: East Germany in the Cold War World, edited by Quinn Slobodian, 131-156. New York: Berghahn Books, 2015.

Schleicher, Ilona. "Elemente entwicklungspolitischer Zusammenarbeit in der Tätigkeit von FDGB und FDJ." In Entwicklungspolitische Zusammenarbeit in der Bundesrepublik Deutschland und der DDR, edited by Hans-Jörg Bücking, 111-138. Berlin: Duncker \& Humblot, 1998. 
Schleicher, Ilona. "FDGB-Offensive in Westafrika: Der Gewerkschaftsverbund im Jahr Afrikas." In Engagiert für Afrika: Die DDR und Afrika II, edited by Ulrich van der Heyden, Hans-Georg Schleicher, and Ilona Schleicher, 82-93. Münster: LIT-Verlag, 1994.

Slobodian, Quinn. "Socialist Chromatism: Race, Racism, and the Racial Rainbow in East Germany." In Comrades of Color: East Germany in the Cold War World, edited by Quinn Slobodian, 23-42. New York: Berghahn Books, 2015.

Wagner, Bernd. "Zu rechtsextremen Entwicklungen in den neuen Bundesländern." In AfrikaBilder. Studien zu Rassismus in Deutschland, edited by Susan Arndt, 109-120. Münster: Unrast, 2006.

Weis, Toni. “The Politics Machine: On the Concept of 'Solidarity' in East German Support für SWAPO". Journal of Southern African Studies 37 (2011): 351-367.

Witkowski, Gregory. "Between Fighters and Beggars: Socialist Philantrophy and the Imagery of Solidarity." In Comrades of Color: East Germany in the Cold War World, edited by Quinn Slobodian, 73-94. New York: Berghahn Books, 2015.

Zelik, Raul. "Nach dem Kapitalismus: Warum der Staatssozialismus ökonomisch ineffizient war und was das für Alternativen heute bedeutet”. Prokla. Zeitschrift für kritische Sozialwissenschaft 39 (2009): 207-227. 